\title{
Influence of Abiotic Factors on Seasonal Incidence of Brinjal Shoot and Fruit Borer, Leucinodes orbonalis Guen. in Varanasi Region
}

\author{
Kantipudi Rajesh Kumar*, N.N. Singh, S.V.S. Raju and Vijay Kumar Mishra
}

Department of Entomology and Agricultural Zoology, Institute of Agricultural Sciences, Banaras Hindu University, Varanasi-221005, Uttar Pradesh, India

*Corresponding author

\section{A B S T R A C T}

\begin{tabular}{|l|}
\hline K e y w o r d s \\
Brinjal crop shoot, \\
Infestation, \\
Leucinodes \\
orbonalis Guen, \\
Seasonal incidence. \\
\hline Article Info \\
\hline $\begin{array}{l}\text { Accepted: } \\
15 \text { March } 2017 \\
\text { Available Online: } \\
10 \text { April } 2017\end{array}$ \\
\hline \hline
\end{tabular}

A field experiment was carried out to investigate the seasonal incidence and influence under unprotected conditions of abiotic factors on infestation of shoot and fruit borer (Leucinodes orbonalis Guenee) in brinjal during Kharif 2013-14 and 2014-15 of Varanasi region. The results revealed that the incidence of shoot and fruit borer and shoot infestation started from first week of August whereas, fruit infestation started from third week of September during both the years. The highest per cent shoot infestation was recorded in second week of September during both the years and the highest per cent fruit infestation of shoot and fruit borer was recorded on third week of October during both years. The shoot and fruit borer was active throughout the cropping season. Among the weather parameters, maximum temperature, minimum temperature, morning relative humidity and sunshine hours showed positive correlation but with rainfall and evening relative humidity showed negative correlation on the incidence of both shoot and fruit infestation by the pest. Thus the management of brinjal shoot and fruit borer during Kharif sown brinjal should therefore be initiated from August onwards using an integrated approach.

\section{Introduction}

Solanum melongena L. commonly known as eggplant, brinjal and aubergine is one of the most popular vegetables grown in many regions of the world (Lawande and Chavan, 1998). Several biotic and abiotic factors directly and indirectly influence the plant growth and the growth and development of insect pests harbouring on the plant and contribute in lowering the yield in brinjal. Among various biotic factors, insect pests are important which greatly affect the quality and productivity of brinjal crop through inflicting a direct damage (Gupta et al., 1987). In the tropics, brinjal production is severely constrained by several insect and mite pests.
The major insect pests of brinjal include fruit and shoot borer (BSFR), leafhopper, whitefly, thrips, aphid, spotted beetles, leaf roller, stem borer, blister beetle and the red spider mite (AVRDC, 2009). Arthropod biodiversity in the brinjal field showed that the brinjal shoot and fruit borer was the major and serious insect pest of brinjal crop. It infests both vegetative as well as reproductive stages of the crop which cause heavy losses in the yield to a tune of 40 to $80 \%$ (AVRDC, 2003). The incidence of this insect pest occurs either sporadically or in outbreak every year in the Indian subcontinent (Dhankar, 1988). Sandanayake and Edirisinghe (1992) reported 
that the larval feeding in fruit and shoot is mainly responsible for the damage to eggplant crop in Sri Lanka. The reduction in yield of brinjal fruits has been reported as high as 70\% (Islam and Karim, 1991 and Dhandapani et al., 2003). The larvae of this pest bore into the tender shoots right from the nursery bed and can cause the apparent yield loss to the tune of 36.4-63.0\% (Kumar and Singh, 2012). The brinjal shoot and fruit borer infestation is responsible for both the qualitative and quantitative degradation of fruits round the year, but it attains the most serious stature during monsoon months (Chowdhury and Kashyap, 1992). The larvae of this pest initially feed on the terminal shoots damaging the growing points. Later these larvae bore into fruits and feed inside the contents making fruits unfit for human consumption (Srinivasan, 2008). Such attacks adversely affect not only the quality, but also the yield of the crop causing considerable economic damage every year. The variability in the pest population and damage can be related to changes in the ambient environment. The best way to avoid pest outbreak is possible when the congenital weather condition for the insect infestation is fully known (Dubey and Thorat, 1994). With a view on the climate change projections for India, an attempt has been made here to study the impact of the likely changes in abiotic factors in relation to shoot and fruit borer on brinjal crop under Varanasi agroclimatic conditions.

\section{Materials and Methods}

The seasonal variation in the incidence of brinjal shoot and fruit borer (BSFB) was studied from the unprotected brinjal plots of $50 \mathrm{~m}^{2}$ area in the vegetable research farm of Institute of Agricultural Sciences, Banaras Hindu University, Varanasi during 2013-2014 and 2014-2015. Thirty days old seedlings of brinjal variety Punjab Sadabahar were transplanted during the second week of July and the standard agronomic package of practices were followed to raise and maintain a healthy crop. Weekly incidence of brinjal shoot and fruit borer from total shoots and fruits were recorded as percentage shoot and fruit infestation from a total of 15 randomly selected plants from the initiation of damage. The data on ecological parameters like maximum temperature, minimum temperature, rainfall, sunshine and relative humidity (morning and evening) have been collected from the meteorological observatory, available at agricultural farm, Institute of Agricultural Sciences, Banaras Hindu University, Varanasi and correlated with the incidence of shoot and fruit borer of brinjal with the help of SPSS 16 software.

\section{Results and Discussion}

\section{Seasonal incidence of brinjal shoot and fruit borer (Leucinodes orbonalis)}

The data on shoot infestation and fruit infestation of brinjal shoot and fruit borer was recorded from first week of July to last week of November during both the years. It is evident from tables 1 and 2 that the shoot infestation of the pest occurred first time in the last week of $\operatorname{July}(2.67 \%, 3.73 \%)$ during both years and attained its peak during second week of September $(24.38 \%, 28.12 \%)$ in both the years of experimentation respectively. While, the fruit infestation initiated from third week of September $(8.47 \%, 12.24 \%)$ and attained its peak during third week of October $(40.32 \%, 43.66 \%)$ in both the years, thereafter there was a gradual decrease in per cent infestation of shoot and fruit till the end of November(7.65\%, $11.24 \%$ in shoots and $24.53 \%, 23.32 \%$ in fruits). Thus after the initiation of fruits, infestation on shoots gradually shifted to fruit thereafter continually decreasing on shoots.

Similar results were also found by Kumar and Singh (2013) where peak pest infestation on shoots observed during $3^{\text {rd }}$ week of September 
and on fruits during $2^{\text {nd }}$ week of October further the studies also revealed that the shoot infestation and fruit infestation gradually decreased during Kharif grown brinjal. Naqvi et al., (2009) also reported that the infestation of $L$. orbonalis Guenee in brinjal shoots started in the first week of August and remained up to second week of October, with peak infestation in second week of September in both the years. Infestation in shoots decreased after fruit setting and completely disappeared thereafter. The infestation in fruits was recorded in the second week of September and remained up to third week of October. The infestation increased gradually and reached maximum in the first week of October $(63.09 \%$ on number and $51.45 \%$ loss on weight basis). The infestation of fruit borer started declining and persisted only up to third week of October. Whereas, Jat et al., (2002) while studying the seasonal incidence of $L$. orbonalis on aubergine cv. Pusa Purple Round. The infestation of shoot borer started from fourth week of August and reached to its peak in the last week of September. The pest started damaging the fruits from first week of October, peaked in the fourth week of October and continued up to second week of December.

Table.1 Influence of abiotic factors on seasonal incidence of shoot and fruit borer,

L. orbonalis during Kharif 2013-14

\begin{tabular}{|c|c|c|c|c|c|c|c|c|c|}
\hline \multirow[t]{2}{*}{$\begin{array}{l}\text { Standard } \\
\text { Week }\end{array}$} & \multirow[t]{2}{*}{$\begin{array}{c}\text { Month } \\
\text { and Date }\end{array}$} & \multirow[t]{2}{*}{$\begin{array}{c}\text { Rainfall } \\
(\mathbf{m m})\end{array}$} & \multicolumn{2}{|c|}{$\begin{array}{c}\text { Temperature } \\
\left({ }^{0} \mathrm{C}\right)\end{array}$} & \multicolumn{2}{|c|}{$\begin{array}{c}\text { Relative } \\
\text { Humidity } \\
(\%)\end{array}$} & \multirow[t]{2}{*}{$\begin{array}{c}\text { Sunshine } \\
\text { Hours }\end{array}$} & \multirow{2}{*}{$\begin{array}{c}\text { "Mean \% } \\
\text { Shoot } \\
\text { Infestation }\end{array}$} & \multirow{2}{*}{$\begin{array}{c}{ }^{*} \text { Mean \% } \\
\text { Fruit } \\
\text { Infestation }\end{array}$} \\
\hline & & & Max. & Min. & Morn & Even & & & \\
\hline 28 & $09-15$ & 81.5 & 28.7 & 19.6 & 86 & 72 & 3.4 & 0.00 & 0.00 \\
\hline 29 & $16-22$ & 0.0 & 33.8 & 18.3 & 83 & 67 & 6.9 & 0.00 & 0.00 \\
\hline 30 & $23-29$ & 48.2 & 31.3 & 19.3 & 86 & 77 & 5.8 & 0.00 & 0.00 \\
\hline 31 & 30-05 Aug & 69.5 & 32.8 & 20.5 & 84 & 75 & 6.7 & 2.67 & 0.00 \\
\hline 32 & Aug 06-12 & 28.6 & 32.9 & 21 & 91 & 76 & 4.6 & 5.73 & 0.00 \\
\hline 33 & 13-19 & 37.4 & 33.6 & 20.7 & 88 & 80 & 6.9 & 9.84 & 0.00 \\
\hline 34 & $20-26$ & 32.3 & 35.1 & 19.2 & 83 & 74 & 6.9 & 12.43 & 0.00 \\
\hline 35 & 27-02 Sep & 150.3 & 33 & 22.7 & 92 & 87 & 1.5 & 18.67 & 0.00 \\
\hline 36 & Sep 03-09 & 3.2 & 34.7 & 22.3 & 80 & 66 & 7.6 & 22.46 & 0.00 \\
\hline 37 & 10-16 & 0.0 & 32.9 & 21.9 & 85 & 66 & 7.2 & 24.38 & 0.00 \\
\hline 38 & $17-23$ & 4.6 & 37.3 & 25.3 & 81 & 76 & 8.0 & 21.72 & 8.47 \\
\hline 39 & 24-30 & 12.2 & 32.4 & 25.5 & 86 & 77 & 6.8 & 19.36 & 14.36 \\
\hline 40 & Oct $01-07$ & 83.9 & 34.2 & 22.3 & 93 & 85 & 3.9 & 17.53 & 23.78 \\
\hline 41 & 08-14 & 44.0 & 35.2 & 24.8 & 84 & 78 & 6.5 & 14.36 & 32.43 \\
\hline 42 & $15-21$ & 17.0 & 38.8 & 19.1 & 92 & 80 & 4.2 & 11.87 & 40.32 \\
\hline 43 & $22-28$ & 0.0 & 38.2 & 19.1 & 88 & 72 & 8.9 & 11.87 & 37.64 \\
\hline 44 & 29-04 Nov & 0.0 & 30.4 & 18.3 & 80 & 76 & 7.8 & 10.32 & 33.46 \\
\hline 45 & Nov $05-11$ & 0.0 & 32.4 & 25.5 & 84 & 60 & 7.6 & 9.68 & 29.57 \\
\hline 46 & $12-18$ & 0.0 & 28.5 & 22.5 & 90 & 48 & 7.9 & 8.43 & 27.34 \\
\hline 47 & $19-25$ & 0.0 & 29.9 & 18 & 89 & 41 & 8.5 & 8.43 & 26.48 \\
\hline 48 & 26-02 Dec & 0.0 & 28.8 & 15.2 & 87 & 46 & 8.1 & 7.65 & 24.53 \\
\hline
\end{tabular}

*Mean of three replications, each having 15 plants 
Table.2 Influence of abiotic factors on seasonal incidence of shoot and fruit Borer, L. orbonalis during Kharif 2014-15

\begin{tabular}{|c|c|c|c|c|c|c|c|c|c|}
\hline \multirow[t]{2}{*}{$\begin{array}{l}\text { Standard } \\
\text { Week }\end{array}$} & \multirow[t]{2}{*}{$\begin{array}{c}\text { Month } \\
\text { and Date }\end{array}$} & \multirow[t]{2}{*}{$\begin{array}{c}\text { Rainfall } \\
\text { (mm) }\end{array}$} & \multicolumn{2}{|c|}{$\begin{array}{c}\text { Temperature } \\
\left({ }^{0} \mathrm{C}\right)\end{array}$} & \multicolumn{2}{|c|}{$\begin{array}{c}\text { Relative } \\
\text { Humidity } \\
(\%)\end{array}$} & \multirow{2}{*}{$\begin{array}{l}\text { Sunshine } \\
\text { Hours }\end{array}$} & \multirow{2}{*}{$\begin{array}{c}\text { *Mean \% } \\
\text { Shoot } \\
\text { Infestation }\end{array}$} & \multirow{2}{*}{$\begin{array}{c}\text { *Mean \% } \\
\text { Fruit } \\
\text { Infestation }\end{array}$} \\
\hline & & & Max. & Min. & Morn. & Even. & & & \\
\hline 28 & $09-15$ & 0.0 & 29.7 & 16.7 & 79 & 63 & 7.9 & 0.00 & 0.00 \\
\hline 29 & $16-22$ & 261.5 & 32.8 & 19.8 & 92 & 84 & 1.4 & 0.00 & 0.00 \\
\hline 30 & $23-29$ & 4.6 & 29.3 & 12.6 & 82 & 65 & 4.8 & 0.00 & 0.00 \\
\hline 31 & 30-05 Aug & 46.0 & 37.8 & 18.7 & 87 & 74 & 5.7 & 3.73 & 0.00 \\
\hline 32 & Aug 06-12 & 142.7 & 32.9 & 16.4 & 87 & 74 & 4.1 & 6.40 & 0.00 \\
\hline 33 & 13-19 & 42.4 & 33.6 & 18.6 & 86 & 79 & 2.4 & 10.93 & 0.00 \\
\hline 34 & $20-26$ & 14.0 & 35.1 & 19.5 & 77 & 60 & 6.7 & 13.00 & 0.00 \\
\hline 35 & 27-02 Sep & 6.5 & 33 & 20.1 & 84 & 71 & 5.3 & 19.85 & 0.00 \\
\hline 36 & Sep 03-09 & 34.9 & 34.7 & 21.4 & 85 & 69 & 6.0 & 23.26 & 0.00 \\
\hline 37 & $10-16$ & 11.0 & 32.9 & 21.8 & 91 & 80 & 4.0 & 28.12 & 0.00 \\
\hline 38 & $17-23$ & 13.7 & 37.3 & 22 & 87 & 72 & 5.2 & 25.37 & 12.24 \\
\hline 39 & $24-30$ & 2.1 & 39.4 & 24.3 & 85 & 56 & 9.3 & 23.48 & 21.93 \\
\hline 40 & Oct $01-07$ & 0.0 & 34.2 & 24.2 & 79 & 64 & 7.2 & 21.84 & 28.86 \\
\hline 41 & 08-14 & 50.7 & 35.2 & 24 & 88 & 68 & 6.1 & 19.84 & 35.36 \\
\hline 42 & $15-21$ & 0.0 & 36.8 & 17.8 & 88 & 69 & 6.8 & 17.63 & 43.66 \\
\hline 43 & $22-28$ & 6.2 & 37.2 & 16.2 & 83 & 58 & 6.8 & 17.63 & 37.48 \\
\hline 44 & 29-04 Nov & 0.0 & 30.4 & 18 & 85 & 41 & 6.8 & 16.48 & 34.13 \\
\hline 45 & Nov $05-11$ & 0.0 & 32.4 & 16.3 & 86 & 39 & 7.2 & 15.74 & 31.85 \\
\hline 46 & $12-18$ & 0.0 & 32.5 & 13.6 & 83 & 37 & 5.4 & 14.23 & 28.64 \\
\hline 47 & $19-25$ & 0.0 & 29.9 & 17 & 89 & 36 & 7.2 & 12.67 & 26.73 \\
\hline 48 & 26-02 Dec & 0.0 & 28.8 & 14.9 & 84 & 49 & 7.3 & 11.24 & 23.32 \\
\hline
\end{tabular}

*Mean of three replications, each having 15 plants.

Table.3 Correlation coefficient (r) of L. orbonalis on brinjal with prevailing weather parameters

\begin{tabular}{|c|c|c|c|c|c|c|c|}
\hline & & Rainfall & $\begin{array}{c}\text { Maximum } \\
\text { Temperature }\end{array}$ & $\begin{array}{c}\text { Minimum } \\
\text { Temperature }\end{array}$ & $\begin{array}{c}\text { Morning } \\
\text { RH } \\
\end{array}$ & $\begin{array}{c}\text { Evening } \\
\text { RH }\end{array}$ & $\begin{array}{c}\begin{array}{c}\text { Sun shine } \\
\text { hours }\end{array} \\
\end{array}$ \\
\hline \multirow{2}{*}{ 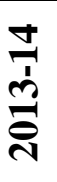 } & Shoot infestation (\%) & -0.065 & 0.388 & 0.583 & 0.004 & -0.084 & 0.134 \\
\hline & Fruit infestation (\%) & -0.364 & 0.222 & 0.014 & 0.239 & -0.242 & 0.328 \\
\hline \multirow{2}{*}{$\frac{n}{\frac{1}{7}}$} & Shoot infestation (\%) & $-0.451^{*}$ & 0.422 & 0.635 & 0.144 & -0.109 & 0.381 \\
\hline & Fruit infestation (\%) & -0.389 & 0.158 & 0.010 & 0.061 & $-0.632^{* *}$ & $0.521^{* *}$ \\
\hline
\end{tabular}




\section{Influence of weather parameters on shoot and fruit borer}

Correlation coefficient between different weather parameters and percent shoot and fruit infestation of shoot and fruit borer during both the years of experimentation revealed that, maximum temperature, minimum temperature, morning relative humidity, sunshine hours recorded positive correlation with a correlation coefficient $r=0.388,0.222$, $0.422,0.158$ for maximum temperature, $\mathrm{r}=0$. $583,0.014,0.635,0.010$ for minimum temperature, $\mathrm{r}=0.004,0.239,0.144,0.061$, for morning relative humidity, $r=0.134$, $0.328,0.381,0.521$ for sunshine hours (Table 3 ), whereas, evening relative humidity and rainfall showed negative correlation $\mathrm{r}=$ $0.084,-0.242,-0.109,-0.632$, for relative humidity, $\mathrm{r}=-0.065,-0.364,-0.451,-0.389$ for rainfall (Table 3) for shoot and fruit infestation respectively.

Earlier reports suggest that there is a positive association of pest population with maximum temperature and minimum temperature by Singh et al., (2011), Shukla et al., (1989), Mathur et al., (2012), morning relative humidity positive correlation and evening relative humidity negative by Kumar and Singh (2013), sunshine hours positive association by Muthukumar and Kalyanasundaram (2003), and rainfall negative correlation by Yadav et al., (2015) and Bapuji Rao and Bhavani (2010). Hence this knowledge of incidence is helpful at what stage the management practices should be initiated to reduce shoot and fruit borer infestation which cause heavy losses to farmers.

\section{Acknowledgement}

The first author is thankful to Department of Science and Technology, New Delhi for providing financial assistance in terms of research award.

\section{References}

AVRDC. 2003. Rearing of eggplant fruit and shoot borer: A slide set and illustrated guide. In: AVRDC Publication No. 99486. Shanhua, Asian Veg. Res. Develop. Centre, Taiwan. p. 12.

AVRDC. 2009. Insect and mite pests on eggplant: A field guide for identification and management. In: AVRDC Publication No. 09-729. Shanhua, The World Vegetable Center: Taiwan., p. 64.

Bapuji Rao, B. and Bhavani, B. 2010. Climate change - Likely effects on the population dynamics of brinjal shoot and fruit borer (Leucinodes orbonalis Guen.), Indian J. Dry land Agric. Res. Dev., 25(2): 58-62.

Chowdhury, O.P. and Kashyap, R.K. 1992. Effect of some management practices on the incidence of insect pests and yield of eggplant (Solanum melongena L.) in India. Trop. Pest Manage., 38(4): 416419.

Dhankar, B.S. 1988. Progress in resistance studies in eggplant (Solanum melongena L.) against shoot and fruit borer (Leucinodes orbonalis Guenee) infestation. Trop. Pest Manage., 34: 343345.

Dhandapani, N., Shalkar, U.R. and Murugan, M. 2003. Bio-intensive pest management in minor vegetable crops: An Indian perspective. J. Food Agri. Environ., 1(2): 330-339.

Dubey, R.C. and Thorat, P.G. 1994. The infestation of jassid on groundnut, sunflower and aphid on safflower at akola (Maharastra) in relation with meterological factors. Plant Prot. Bull., 46(1): 43-47.

Gupta, H.C.L., Mehta, S.C. and Pareek, B.L. 1987. Bioefficiency and residue of carbaryl investigation in/on brinjal. Veg. Sci., 14(2): 185-194.

Islam, M.N. and Karim, M.A. 1991. Management of the brinjal shoot and fruit borer, Leucinodes orbonalis Guenee (Lepidoptera: Pyralidae) in field. In: 
Annual Research Report. Entomology Division, Bangladesh Agric. Res. Inst. Joydabpur, Gazipur. pp. 44-46.

Jat, K.L., Pareek, B.L. and Singh, S. 2002. Seasonal incidence of shoot and fruit borer (Leucinodes orbonalis Guen.) on eggplant (Solanum melongena L.) in Rajasthan. Ann. Biol., 18(2): 165-169.

Kumar, S. and Singh, D. 2013. Seasonal incidence and economic losses of brinjal shoot and fruit borer, Leucinodes orbonalis Guenee. Agric. Sci. Digest., 33(2): 98-103.

Kumar, S. and Singh, D. 2012. Seasonal fluctuation and extent of losses of Leucinodes orbonalis Gueneeon Solanum melongena L. Ann. Pl. Protec. Sci., 20: 318-321.

Lawande, K.E. and Chavan, J.K. 1998. Eggplant (Brinjal) in: D.K. Salunkhe and $\mathrm{S}>\mathrm{S}$. Kadam (Eds.) "Handbook of vegetable Science and Technology. Production, compostition, storage.

Mathur, Anjali., Singh, N.P., Mahesh, M. and Singh, S. 2012. Seasonal incidence and effect of abiotic factors on population dynamics of major insect pests on brinjal crop. J. Environ. Res. Develop., 7(1A): 421-435.

Muthukumar and Kalyanasundaram, M. 2003. Influence of abiotic factors on the incidence of major insect pests in brinjal (Solanum melongena L.). South Indian Horticulture, 51(1/6): 214-218.
Naqvi, A.R., Pareek, B.L. and Mitharwal, B.S. 2009. Seasonal incidence of shoot and fruit borer, Leucinodes orbonalis guenee infesting brinjal in hyper arid region of Rajasthan. J. Insect Sci., 22(2): 195-198.

Nonnecke, J.L. 1989. Vegetable production. Van Nostrand Reinhold, New York. 247p.

Sandanayake, W.R.M. and Edirisinghe, J.P. 1992. Trathala flavoorbitalis, parasitization and development in relation to host stage attacked. Insect Sci. its Application, 13(3): 287-292.

Shukla, R.P. 1989. Population fluctuation of Leucinodes orbonalis on brinjal (Solanum melongena) in relation to abiotic factors in Meghalaya. Indian J. Agric. Sci., 59(4): 260-264.

Srinivasan, B. 2008. Integrated pest management for eggplant fruit and shoot borer (Leucinodes orbonalis) South and South East Asia, past, present and future. J. Biopest., 1(2): 105-112.

Singh, R.K.R., Singh, T.K. and Shah, M.A.S 2011. Population incidence of brinjal shoot and fruit borer, Leucinodes orbonalis Guen (Lepidoptera: Pyralidae) in Manipur. J. Exp. Zool., India, 14(1): 229-232.

Yadav, A., Raghuraman, M. and Choudhary, S. 2015. Impact of abiotic factors on population dynamics of fruit and shoot borer, Leucinodes orbonalis (guen.) in brinjal Solanum melongena L. J. Experimental Zool., 18(2): 765-768.

\section{How to cite this article:}

Kantipudi Rajesh Kumar, N.N. Singh, S.V.S. Raju and Vijay Kumar Mishra. 2017. Influence of Abiotic Factors on Seasonal Incidence of Brinjal Shoot and Fruit Borer, Leucinodes orbonalis Guen. in Varanasi Region. Int.J.Curr.Microbiol.App.Sci. 6(4): 1513-1518. doi: https://doi.org/10.20546/ijcmas.2017.604.185 